\title{
Influence of Priming Duration on the Performance of Amaranths (Amaranthus cruentus L.) in Sokoto Semiarid Zone of Nigeria
}

\author{
Mukhtar Musa, ${ }^{1}$ Ajit Singh, ${ }^{2}$ and Aminu Aliyu Lawal ${ }^{1}$ \\ ${ }^{1}$ Department of Crop Science, Usmanu Danfodiyo University, P.M.B. 2346, Sokoto, Sokoto State, Nigeria \\ ${ }^{2}$ School of Biosciences, Faculty of Science, The University of Nottingham, Malaysia Campus, CB 12 Red Building, \\ Jalan Broga, 43500 Semenyih, Selangor, Malaysia
}

Correspondence should be addressed to Mukhtar Musa; mbmukhtar@gmail.com

Received 30 June 2013; Accepted 21 October 2013; Published 19 January 2014

Academic Editor: Bernd Lennartz

Copyright (C) 2014 Mukhtar Musa et al. This is an open access article distributed under the Creative Commons Attribution License, which permits unrestricted use, distribution, and reproduction in any medium, provided the original work is properly cited.

\begin{abstract}
Two field trials were conducted during the 2012 cropping season at the Fruits and Vegetable Teaching and Research Farm of the Department of Crop Science, Usman Danfodiyo University, Sokoto (located on latitude $14^{\circ} \mathrm{N}-15^{\circ} \mathrm{N}$ and longitude $4^{\circ}-5^{\circ}$ ), to evaluate the effect of priming duration on the growth and yield of amaranth. Treatments consisted of four priming durations (2, 4,6 , and 8 hours) and control (where no priming was applied). The treatments were laid out in a completely randomized design (CRD) replicated three times for the germination test and randomized complete block design (RCBD) for the field trial. Data were collected on days to $50 \%$ germination, percentage germination, days to $50 \%$ emergence, and percentage emergence. Results revealed significant effect of priming duration on days to $50 \%$ germination, percentage germination, and days to $50 \%$ emergence. Soaking seeds for 2 hours reduced the number of days to $50 \%$ germination and emergence and also recorded higher germination. Thus, from the findings of this study, it could be concluded that priming amaranth seeds for 2 hours could be applied to enhance amaranth production.
\end{abstract}

\section{Introduction}

Amaranth (Amaranthus cruentus L.) is an important leaf vegetable crop cultivated throughout the tropics. The leaves are rich in vitamin $\mathrm{A}$, calcium, and potassium. The seeds of grain amaranth are valued for their high protein content (up to $15 \%)$. Amaranth represents the largest source of nutrients of all the vegetables that can be grown in tropical Africa. The leaves of A. cruentus (edible part) represent $76 \%$ of the total fresh weight of shoots. One hundred grams contain $84 \mathrm{~g}$ water, $4.6 \mathrm{~g}$ protein, $1.8 \mathrm{~g}$ cellulose, $410 \mathrm{mg}$ calcium, $8.9 \mathrm{mg}$ iron, $5.7 \mathrm{mg}$ beta-carotene, and $64 \mathrm{mg}$ vitamin C [1].

Despite the role of amaranth as one of the sources of vitamins $A$ and $B$, thiamine, niacin, riboflavin, and some other dietary minerals such as calcium, iron, potassium, zinc, copper, and manganese [1], its Production in Nigeria still remains low as compared to other countries. There is therefore a need to improve its production to meet the demand of the consumers. Seed priming has been identified as the simplest method to improve establishment and subsequent performance of most crops in the tropics where favorable conditions during germination seldom occur. Seed priming prior to planting enhances germination and seedlings growth by controlling the imbibition and reducing the vagaries of adverse weather and soil condition [2]. Seed priming is a practical method to improve rates and uniformity of germination [3]. The effect of priming has been attributed to metabolic repair and activation of seed during water imbibition [4-6].

Hydropriming (hydration of seed with water only) is the simplest approach to increase the percentage and rate of germination and the uniformity of stand establishment under stress conditions especially in dry areas [7-9]. Moosavi et al. [10] reported that hydropriming of amaranth seeds significantly increased germination percentage, speed of germination, root length, and seed vigour in all cultivars. Priming 
leads to cellular, subcellular, and molecular changes in seeds and subsequently promotes seed vigor during germination and emergence in different plant species [11].

Thus, this experiment was conducted to study the effect of seed priming on the performance of amaranth in semiarid environment.

\section{Methodology}

The experiment was carried out during the 2012 cropping season and, for both the first and second trials, treatments consisted of four priming durations (2, 4, 6, and 8 hours) and a control (where no priming was applied) making a total of five (5) treatment combinations laid out in completely randomized design (CRD) replicated three times.

2.1. Seed Priming. Seed priming was carried out in the Crop Science Laboratory, Usmanu Danfodiyo University, Sokoto. Seeds of the existing amaranths cultivar were sourced from Sokoto Agricultural Development Programme in Sokoto, Nigeria. The seeds were primed (soaked) in water (hydropriming) for 2, 4, 6, and 8 hours and control (where no priming was applied). $500 \mathrm{~mL}$ of water and $50 \mathrm{~g}$ of seeds all were used for each treatment. After priming, seeds were air-dried back to their initial moisture content. At the time of experiment, the temperature of the natural water during priming was $29^{\circ} \mathrm{C}$ and $28^{\circ} \mathrm{C}$ for the first and the second trials, respectively.

2.2. Germination Test. For both trials, 30 seeds were placed on moist filter paper of $90 \mathrm{~mm}$ in diameter in petri dishes for each treatment and replicated three times. Droplets of water were applied everyday on the filter paper to provide adequate moisture for seed germination. Seed was considered germinated when the radicle emerged through the seed coat. Germination count was taken daily for 14 days. Germination percentage was computed using the following:

$$
\text { Germination percentage }=\frac{\text { Total seeds germinated }}{\text { Total seeds sown }} \times 100 \text {. }
$$

2.3. Field Emergence. The emergence test was carried out at the Fruits and Vegetable Teaching and Research Farm of Usmanu Danfodiyo University, Sokoto. Sokoto is located on latitude $14^{\circ} \mathrm{N}-15^{\circ} \mathrm{N}$ and longitude $4^{\circ}-5^{\circ} \mathrm{E}$ [12]. Annual rainfall ranges from $380 \mathrm{~mm}$ to $763 \mathrm{~mm}$; the dry season starts from October and ends in May or June. During both trials, the seeds were sown through drilling method with a row-torow spacing of $20 \mathrm{~cm}$ at a depth of $0.5-1 \mathrm{~cm}$. Gross plot size was $2 \mathrm{~m} \times 2 \mathrm{~m}\left(4 \mathrm{~m}^{2}\right)$ and the net plot was $1.6 \mathrm{~m} \times 1.6 \mathrm{~m}$ $\left(2.56 \mathrm{~m}^{2}\right)$. Emergence test involves counting the number of plants that emerged on the soil surface. It was computed using the following:

$$
\text { Emergence percentage }=\frac{\text { Emerged seeds }}{\text { Number of seeds sown }} \times 100 \text {. }
$$

TABLE 1: Days to 50\% germination of amaranths as influenced by priming duration during the 2012 cropping season.

\begin{tabular}{lccc}
\hline Treatments & First trial & Second trial & Combined \\
\hline Duration $(\mathrm{h})$ & & & \\
0 & 2.3 & $4.0^{\mathrm{a}}$ & $3.2^{\mathrm{a}}$ \\
2 & 1.9 & $2.5^{\mathrm{b}}$ & $2.2^{\mathrm{b}}$ \\
4 & 1.9 & $2.1^{\mathrm{b}}$ & $2.0^{\mathrm{b}}$ \\
6 & 1.9 & $2.8^{\mathrm{b}}$ & $2.3^{\mathrm{b}}$ \\
8 & 2.1 & $2.0^{\mathrm{b}}$ & $2.0^{\mathrm{b}}$ \\
SE $( \pm)$ & 0.14 & 0.32 & 0.19 \\
Significance & $\mathrm{ns}$ & $*$ & $*$ \\
\hline
\end{tabular}

Means in a column followed by same letter(s) in a superscript within a treatment group are not significantly different using LSD at 5\% level; ns: not significant; $*$ : significant.

Data were collected on days to $50 \%$ germination, percentage germination, days to $50 \%$ emergence, and percentage emergence. The data collected were subjected to analysis of variance (ANOVA) procedure for completely randomized design (CRD) using SAS computer package. Means showing significant differences were separated using least significant difference (LSD) test.

\section{Results and Discussions}

\subsection{Seed Germination}

3.1.1. Days to $50 \%$ Germination. Significant $(P<0.05)$ effect of priming duration on days to $50 \%$ germination of amaranth was observed during the second trial and the combined (Table 1). Days to $50 \%$ germination was achieved faster with primed seeds in the second trial $(2.5,2.1,2.8$, and 2.0 for $2,4,6$, and 8 hours, resp.) and the combined (2.2, 2.0, 2.3, and 2.0 for $2,4,6$, and 8 hours, resp.) than unprimed seeds (4.0 and 3.2 in the second trial and the combined, resp.). Faster seed germination recorded in the primed seeds could be as a result of softening the seed coat, thereby making it easier for the radicle to protrude through it and become germinated compared to the unprimed seeds. This is in line with the findings of Moosavi et al. [10] who reported that seed priming has positive effects on germination characteristics of amaranth as a result of increased peroxidase activity.

3.1.2. Percentage Germination. Significant $(P<0.05)$ effect of priming duration on percentage germination of amaranth was observed during the second trial and the combined (Table 2). Higher percentage germination was recorded with second trial $(82.1,84.5,80.4$, and 84.2 for $2,4,6$, and 8 hours, resp.) and combined $(79.5,81.5,79.5$, and 80.4 for $2,4,6$, and 8 hours, resp.) in primed seeds than unprimed (68.3 and 70.3 in second trial and the combined, resp.). This may be attributed to faster absorption of water by the seeds during priming which activates germination process within the seeds but radicle did not emerge through the seed coat. This agrees with results reported by Ascherman-Koch et al. [13] who reported that primed seeds have better efficiency for 
TABLE 2: Percentage germination of amaranths as influenced by priming duration during the 2012 cropping season.

\begin{tabular}{lccc}
\hline Treatments & First trial & Second trial & Combined \\
\hline Duration $(\mathrm{h})$ & & & \\
0 & 72.3 & $68.3^{\mathrm{b}}$ & $70.3^{\mathrm{b}}$ \\
2 & 76.9 & $82.1^{\mathrm{a}}$ & $79.5^{\mathrm{a}}$ \\
4 & 78.3 & $84.5^{\mathrm{a}}$ & $81.5^{\mathrm{a}}$ \\
6 & 78.5 & $80.4^{\mathrm{a}}$ & $79.5^{\mathrm{a}}$ \\
8 & 76.7 & $84.2^{\mathrm{a}}$ & $80.4^{\mathrm{a}}$ \\
SE $( \pm)$ & 2.63 & 2.44 & 1.97 \\
Significance & $\mathrm{ns}$ & $*$ & $*$ \\
\hline
\end{tabular}

Means in a column followed by same letter(s) in a superscript within a treatment group are not significantly different using LSD at 5\% level; ns: not significant; $*$ : significant.

water absorption from imbibitions medium and it is obvious that metabolic activities in seed during the germination process commence much earlier than the emergence of the radicle and plumule. The differences in germination between primed and control seeds were expected. Such differences were the expected results of earlier activation of physiological process of germination in primed seeds, starting earlier than unprimed seeds. Moreover, priming probably improved germination through enzyme activation and softening of the seed coat [14].

\subsection{Seedling Emergence}

3.2.1. Days to $50 \%$ Emergence. Significant $(P<0.05)$ effect of priming duration on days to $50 \%$ emergence of amaranth was observed during the trial (Table 3 ). Faster seedling emergence was observed for seeds primed for 2, 4, and 6 hours (which recorded 3.3, 3.1, and 2.8, resp.) compared to those primed for 8 hours (5.8) and unprimed (5.7). The finding here could be attributed to the benefits of seed priming in enzyme activation and initiation of germination process that gives the seeds a better start during soaking compared to the unprimed. This agrees with the findings of AschermanKoch et al. [13] who reported that primed seeds had better efficiency for water absorption from imbibitions medium and it is obvious that metabolic activities in seed during the germination process commence much earlier than the emergence of the radicle and plumule. Bailly et al. [15] found that primed seeds of sunflower emerged 1-3 days earlier than nontreated seeds and it quickly becomes apparent that these early grains led to a range of later benefits. Also, Basra et al. [5] reported that primed seeds emerged 12 hours earlier than nonprimed seeds.

3.2.2. Percentage Emergence. No significant $(P>0.05)$ effect of priming duration on percentage emergence of amaranths was observed during the trial (Table 4).

\section{Conclusions}

From the findings of this research, it could be concluded that amaranth primed for 2 hours produces better performance
TABLE 3: Days to $50 \%$ emergence of amaranths as influenced by priming duration during the 2012 cropping season.

\begin{tabular}{lccc}
\hline Treatments & First trial & Second trial & Combined \\
\hline Duration $(\mathrm{h})$ & & & \\
0 & $5.7^{\mathrm{a}}$ & 2.7 & 4.17 \\
2 & $3.3^{\mathrm{b}}$ & 2.7 & 3.0 \\
4 & $3.1^{\mathrm{b}}$ & 2.8 & 3.0 \\
6 & $2.8^{\mathrm{b}}$ & 3.8 & 3.3 \\
8 & $5.8^{\mathrm{a}}$ & 2.9 & 4.3 \\
SE $( \pm)$ & 0.43 & 0.46 & 0.43 \\
Significance & $*$ & $\mathrm{~ns}$ & $\mathrm{~ns}$ \\
\hline
\end{tabular}

Means in a column followed by same letter(s) in a superscript within a treatment group are not significantly different using LSD at 5\% level; ns: not significant; $*$ : significant.

TABle 4: Percentage emergence of amaranths as influenced by priming duration during the 2012 cropping season.

\begin{tabular}{lccc}
\hline Treatments & First trial & Second trial & Combined \\
\hline Duration (h) & & & \\
0 & 79.3 & 59.7 & 69.5 \\
2 & 67.5 & 69.5 & 68.5 \\
4 & 70.3 & 60.0 & 65.2 \\
6 & 74.4 & 68.5 & 71.5 \\
8 & 54.6 & 56.9 & 55.8 \\
SE $( \pm)$ & 6.70 & 6.80 & 5.80 \\
Significance & $\mathrm{ns}$ & $\mathrm{ns}$ & $\mathrm{ns}$ \\
\hline
\end{tabular}

Means in a column followed by same letter(s) in a superscript within a treatment group are not significantly different using LSD at 5\% level; ns: not significant; $*$ : significant.

with respect to days to $50 \%$ germination, percentage germination, and days to $50 \%$ emergence. The implication of this research is that farmers in and around the study area, can now soak amaranths seeds in water for two hours so as to improve their performance.

\section{Conflict of Interests}

The authors of this paper have no financial relation whatsoever that can lead to conflict of interests.

\section{References}

[1] R. H. Raemaekers, Crop Production in Ttropical Africa, DGIC Belgium, 2001.

[2] M. B. McDonald, "Seed deterioration: physiology, repair and assessment," Seed Science and Technology, vol. 27, no. 1, pp. 177237, 1999.

[3] C. A. Parera and D. J. Cantliffe, "Pre-sowing seed priming," Horticultural Reviews, vol. 16, pp. 109-141, 1994.

[4] A. S. Basra, S. Bedi, and C. P. Malik, "Accelerated germination of maize seeds under chilling stress by osmotic priming and associated changes in embryo phospholipids," Annals of Botany, vol. 61, no. 5, pp. 635-639, 1988.

[5] S. M. A. Basra, I. Afzal, R. A. Rashid, and A. Hameed, "Inducing salt tolerance in wheat by seed vigor enhancement techniques," 
International Journal of Biology and Biotechnology, vol. 2, pp. 173-179, 2005.

[6] C. M. Bray, P. A. Davison, M. Ashraf, and R. M. Taylor, "Biochemical changes during osmopriming of leek seeds," Annals of Botany, vol. 63, no. 1, pp. 185-193, 1989.

[7] J. N. Berchie, H. Adu-Dapaah, J. Sarkodie-Addo et al., "Effect of seed priming on seedling emergence and establishment of four bambara groundnut (Vigna subterranea L. Verdc.) landraces," Journal of Agronomy, vol. 9, no. 4, pp. 180-183, 2010.

[8] L. J. Clark, W. E. Whalley, J. Ellis-Jones, K. Dent, and H. R. Rowsea, "On farm seed priming in maize: a physiological evaluation," in Proceeding of the 7th Eastern and South Africa Regional Maize Conference, pp. 268-273, February 2001.

[9] K. Mavi, S. Ermis, and I. Demir, "The effect of priming on tomato rootstock seeds in relation to seedling growth," Asian Journal of Plant Sciences, vol. 5, no. 6, pp. 940-947, 2006.

[10] A. Moosavi, R. Tavakkol Afshari, F. Sharif-Zadeh, and A. Aynehband, "Effect of seed priming on germination characteristics, polyphenoloxidase, and peroxidase activities of four amaranth cultivars," Journal of Food, Agriculture and Environment, vol. 7, no. 3-4, pp. 353-358, 2009.

[11] J. Cuartero, M. C. Bolarín, M. J. Asíns, and V. Moreno, "Increasing salt tolerance in the tomato," Journal of Experimental Botany, vol. 57, no. 5, pp. 1045-1058, 2006.

[12] A. G. Ojanuga, "Agro ecological zones of Nigerian MAPS," National Special Programme on Food Security, FAO-UNESCO, 2004.

[13] C. Ascherman-Koch, P. Hofmann, and A. M. Steiner, "Presowing treatment for improving quality in cereals," Germination and Vigor, Seed Science Technology, vol. 20, pp. 435-440, 1992.

[14] A. Singh, R. Dahiru, and M. Musa, "Osmopriming duration influence on germination, emergence and seedling growth of sorghum," Seed Technology, vol. 34, no. 1, pp. 111-118, 2012.

[15] C. Bailly, A. Benamar, F. Corbineau, and D. Côme, "Antioxidant systems in sunflower (Helianthus annuus L.) seeds as affected by priming," Seed Science Research, vol. 10, no. 1, pp. 35-42, 2000. 


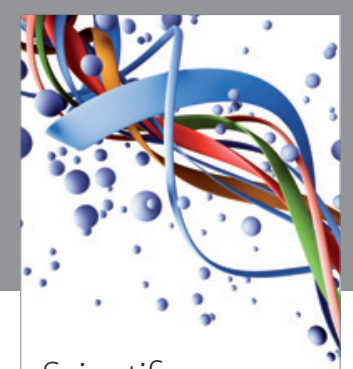

Scientifica
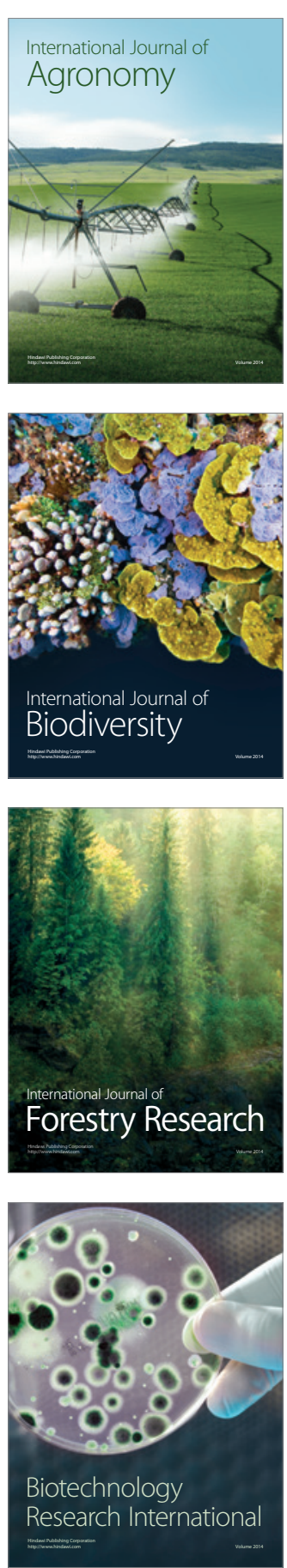
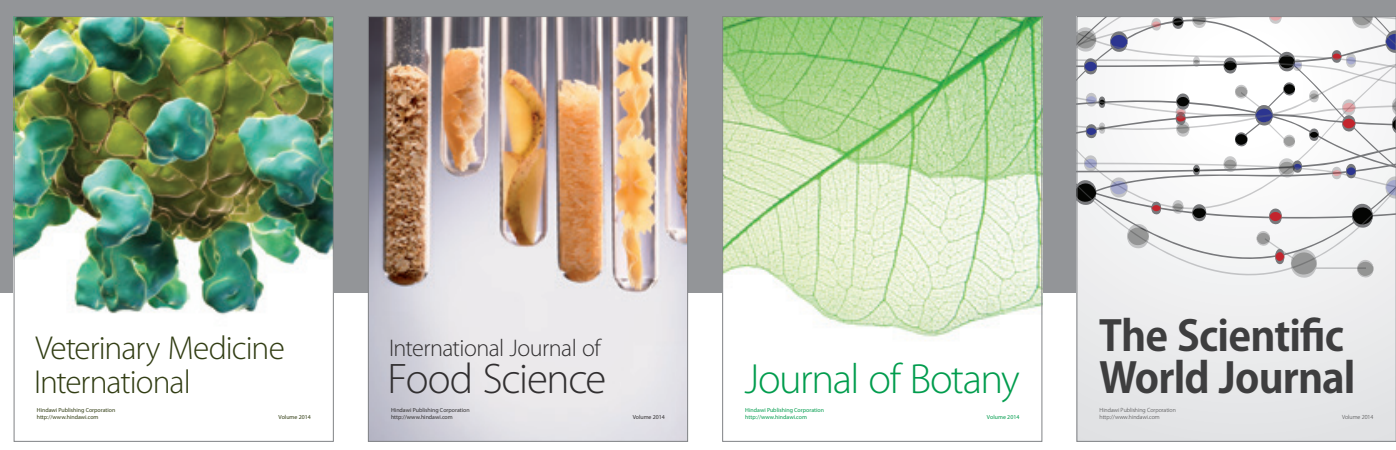

The Scientific World Journal
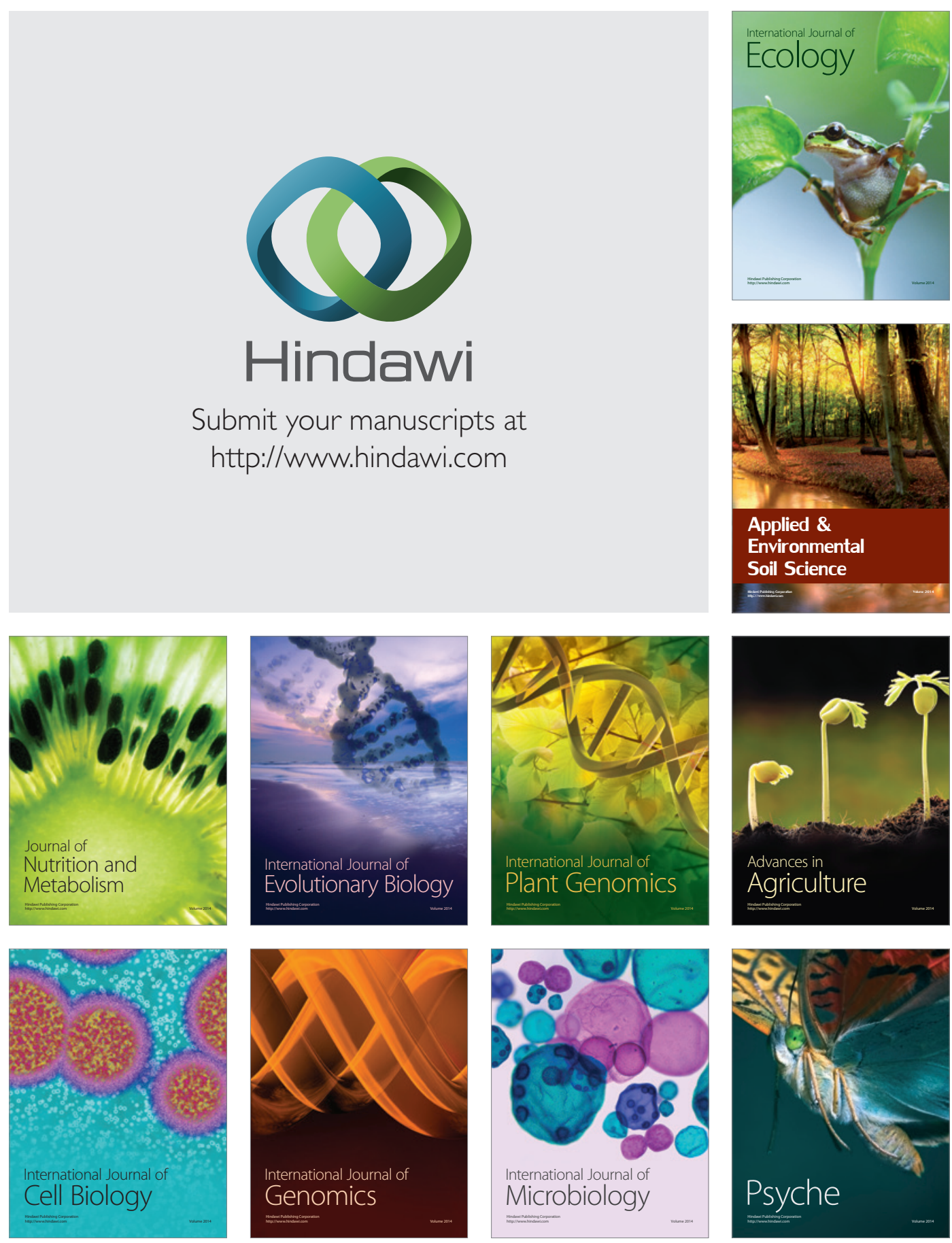